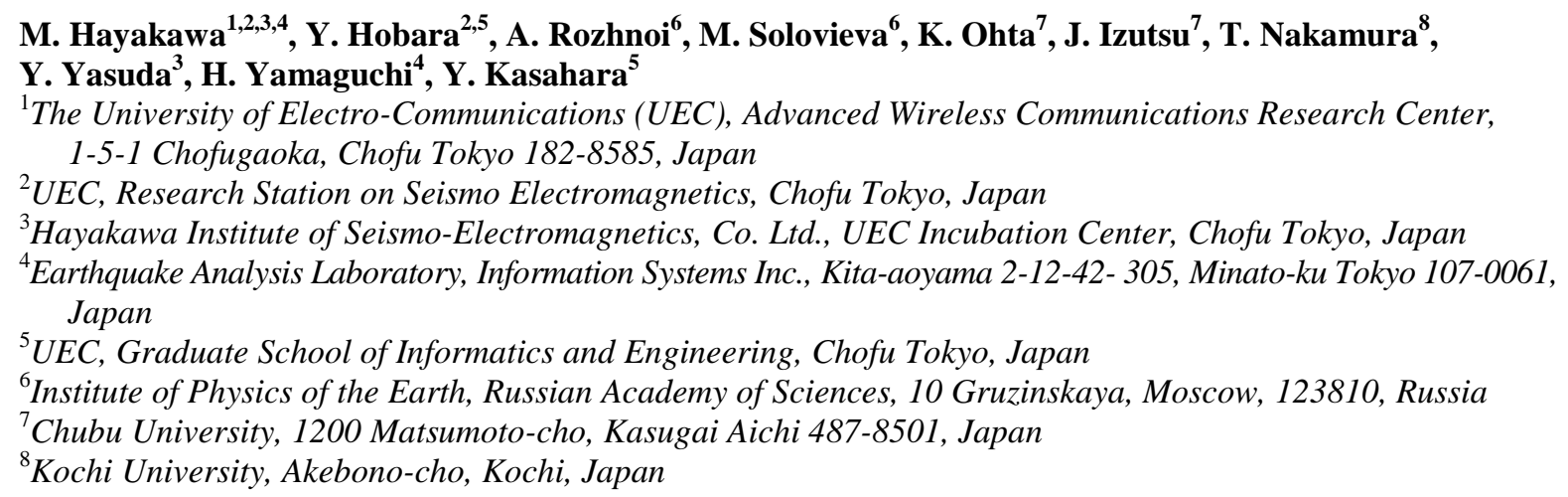

\title{
THE IONOSPHERIC PRECURSOR TO THE 2011 MARCH 11 EARTHQUAKE AS BASED ON THE JAPAN-PACIFIC SUBIONOSPHERIC VLF/LF NETWORK OBSERVATION
}

By using the network observation of subionospheric VLF/LF signals in Japan and in Russia, we have found a significant ionospheric perturbation prior to the recent 2011 March 11 Japan earthquake (EQ) in the off-sea of the Tohoku area, which was an exceptionally huge plate-type EQ. A remarkable anomaly (with decrease in the nighttime amplitude and also with enhancement in dispersion) has been detected on March 5 and 6 on the propagation path from the NLK transmitter (Seattle, USA) to Chofu (together with Kochi and Kasugai), and also we have observed the corresponding VLF anomaly during a prolonged period of March 1-6, with minima in the nighttime amplitude on March 3 and 4 on the path from JJI transmitter (Miyazaki, Kyushu) to Kamchatka, Russia. Fig. 4 . Bibliogr.: 27 ref.

Key words: ionospheric precursor, VLF/LF subionospheric propagation, 2011 March 11 Japan earthquake.

It is recently agreed that there exist electromagnetic precursors to earthquakes (EQs) [1-6]. The observation of seismo-electromagnetic and related phenomena can be customarily classified into the two categories: (1) direct effects emitted from the lithosphere and received on the Earth's surface, and (2) the indirect effects of EQs which are the perturbations (or disturbances) taking place either in the atmosphere or in the ionosphere due to pre-EQ lithospheric activities. As for the first category, there are observed lithospheric emissions in a wide frequency range from DC/ULF to VHF (very high frequencies) or even higher. The first example is the DC (direct current) geoelectric signals [7], and the second example is ULF (ultra low frequency) electromagnetic emissions which seems to be very promising for EQ prediction (e.g., see [8-10]). As for the second category, there are several techniques to reveal atmospheric and ionospheric precursors, including satellite infrared sensors, vertical sounding of the ionosphere from the ground, GPS observations, in-situ plasma observations, etc. [11]. Probing by anomalous propagation of radio waves is one of the methods. The further reviews on the second category have been published on the atmospheric perturbations [12] and on the ionospheric perturbations [13-15].

Among different kinds of electromagnetic precursors mentioned above, the ionospheric perturbations belonging to the second category seem to be the most reliable because there have been accumulated a substantial number of VLF/LF (very low frequency/low frequency) works including both case and statistical studies summarized in [13]. Recently the lower ionospheric perturbation as detected by sub-ionospheric VLF/LF propagation is shown to be statistically significantly correlated with the EQs, which take place within the wave sensitive area around the propagation path and with magnitudes tentatively greater than 6.0 and shallower depth $(<40 \mathrm{~km})[16,17]$. These papers were based on an abundant number of the inland EQs during seven years, which lend a further support to our previous similar statistical studies though based on the less number of events and during smaller time periods [18-20]. The similar statistical correlation has also been obtained by Liu [14] between the upper ionosphere and EQs on the basis of vertical sounding from the ground and GPS TEC (total electron contents) observation. These together suggest that the ionosphere is extremely sensitive to the pre-seismic activity not only in the lower region, but also in the F2 layer. A few possible mechanisms for seismoionospheric perturbations have already been proposed (e.g., [2, 3, 21]), but it is not well understood at the moment which mechanism is dominant.

Concurrently with the above-mentioned statistical studies, we are interested in the case studies of huge EQs, because these are of vital importance in investigating the detailed temporal/spatial characteristics of such seismoionospheric perturbations, and also their relationship is significant with the corresponding lithospheric and atmospheric phenomena. Our former case studies included, (1) Kobe EQ (17 January, 1995) 
(2) Tokachi-oki EQ (25 September, 2003) (3) Niigata-chuetsu EQ (23 October 2004) (4) the 1999 Chi-chi EQ in Taiwan (5) the 2004 Sumatra EQ. Details of impact of these EQs are summarized in review [13]. All these EQs except the Tokachi-oki and Sumatra EQs were of the land-type due to fault activity, so we know characteristics of ionospheric perturbations from the inland EQs having in mind the above-mentioned statistical studies [16, 17].

The 2011 Japan EQ was extremely huge, of 9.0 magnitude, and it belongs to oceanic EQs taken place in the Pacific Ocean due to the plate movement. It is interesting to search for the ionospheric perturbation preceding this oceanic $\mathrm{EQ}$, and, if so, to compare characteristics of oonospheric perturbations from this sea EQ with the former properties of many inland EQs.

1. The 2011 Tohoku EQ. There happened an extremely huge EQ (with magnitude of 9.0) under the seabed in the Pacific Ocean off the Tohoku area of Japan, which is formally named the EQ of the 2011 off the Pacific coast of Tohoku. This EQ took place at 14:46:18 LT on March 11, 2011 with its epicenter at the geographic coordinates $\left(36^{\circ} 6.2^{\prime} \mathrm{N}\right.$, $142^{\circ} 51.6^{\prime} \mathrm{E}$ ) as shown in Fig. 1 by a red star with its date and its depth of $\sim 20 \mathrm{~km}$. This event was a typical oceanic EQ of the plate type just around Japan, which is completely different from the extensively-studied fault-type EQs such as Kobe EQ, Niigata-chuetsu EQ, etc.

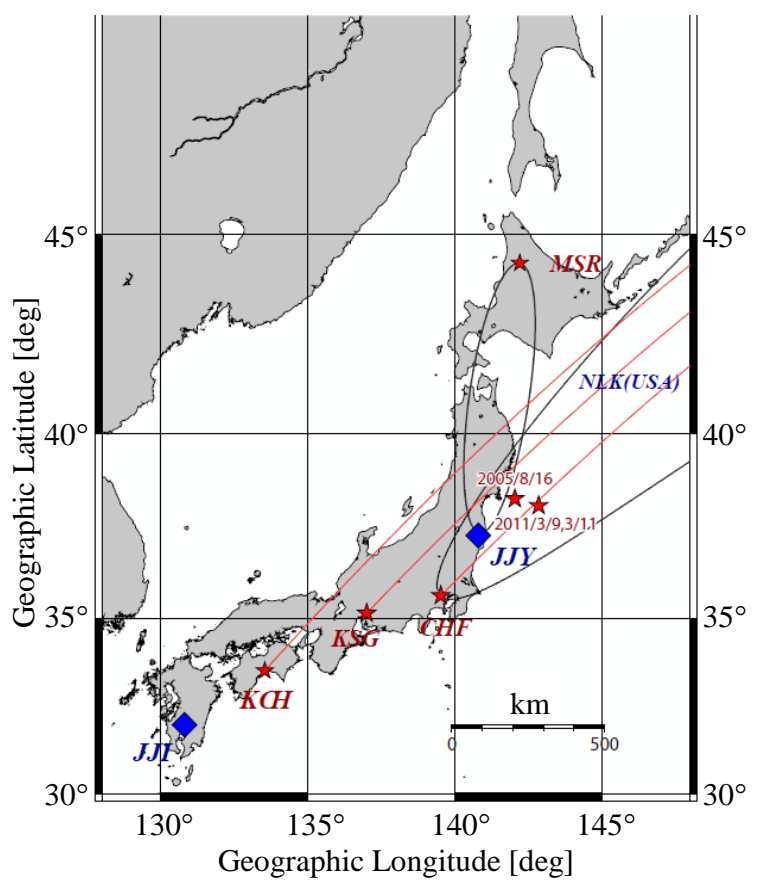

Fig. 1. Location of Japanese VLF/LF transmitters JJY (Fukushima) and JJI (Miyazaki) (blue diamonds) and the VLF/LF receiving stations (by red stars). Ellipse outlines the wave sensitive area of propagation path NLK-CHF. Epicenters of the main shock and its foreshock are indicated with the red stars marked by corresponding dates
2. VLF/LF subionospheric network. We established the Japanese and the Pacific network for sub-ionospheric VLF/LF propagation just after the 1995 Kobe EQ within the framework of the former NASDA's frontier project [21]. This network observation has been continued for over 15 years until now. The main observatories within Japan at the moment are (1) Moshiri in Hokkaido (abbreviated as MSR), (2) Chofu in Tokyo (CHF), (3) Kasugai near Nagoya (KSG), (4) Kochi in Shikoku island (KCH), and (5) Tsuyama, Okayama (TYM). These are shown by red stars in Fig. 1, although TYM is not illustrated in the figure. Some additional observatories are planned to be built shortly. At each receiving station, we normally detect simultaneously the signals from two Japanese transmitters with call signs of JJY (in Fukushima, $40 \mathrm{kHz}$ ) and JJI (in Miyazaki, Kyusyu, $22.2 \mathrm{kHz}$ ) as shown by blue diamonds in Fig. 1 and also a few foreign transmitters, i.e., NWC (NorthWest Cape, Australia), NPM (Hawaii), and NLK (Seattle, USA)). The details of this VLF/LF network and corresponding VLF receiving system can be found in [13, 16, 17, 21].

This sub-ionospheric VLF/LF network was extended to cover a wider area of the Pacific ocean by including a station in Taiwan [22] and in collaboration with Russian colleagues a station in Russia, Petropavlovsk-Kamchatsky (PTK) shown by green dot in Fig. 2 [3]. Observations at PTK were performed very regularly resulting in significant scientific merits [23-25]. The Russian group has recently established one more station at YuzhnoSakhalinsk (YSH) also show by a green dot in Fig. 2. These two stations are equipped with the same type of VLF/LF receiving system as used at Japanese stations.

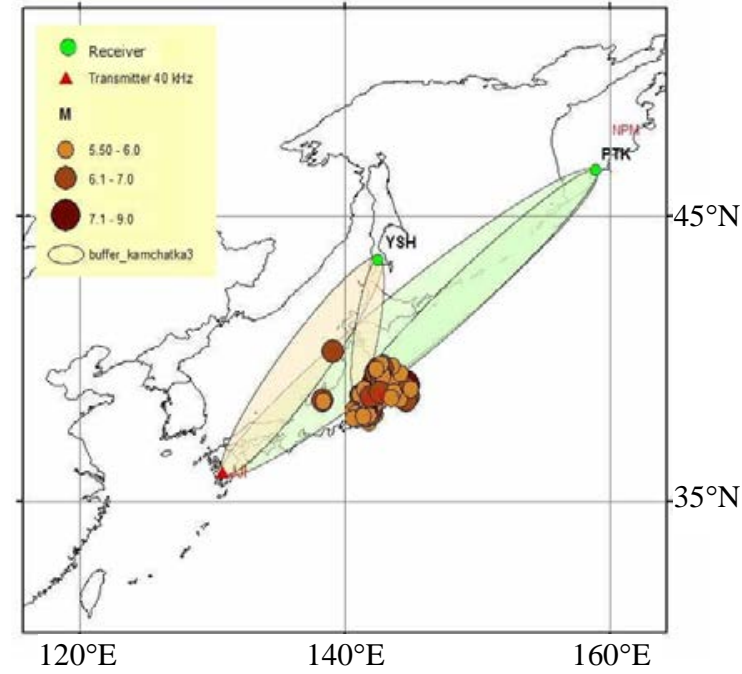

Fig. 2. Position of Japanese VLF/LF transmitters JJY and JJI (triangles) and observatories PTK and YSH (green dots). Elliptic wave sensitive areas are plotted for the paths JJY-YSH, JJY-PTK, JJI-YSH, and JJI-PTK. The main shocks and aftershocks are show by circles of size being proportional to the EQ magnitude 
3. Observational results and analysis method. Fig. 1 illustrates three paths from NLK transmitter (Seattle, USA) to Japanese VLF/LF observatories CHF, KSG and KCH. The fifth Fresnel zone is plotted by thin ellipse for the propagation path NLK-CHF being the wave sensitive area for this path. This means that any EQ taking place within sensitive area results in a significant changes in VLF radio signal received at the observatory (either in amplitude or in phase, or both).

Concerning the analysis, we do not follow the terminator-time method initially developed for the Kobe EQ [26], but apply an alternative «the nighttime fluctuation method» [16-20], in which we investigate only the nighttime amplitude data. The nighttime fluctuation method is much simpler in application than the terminator-time method. We first read the amplitude $A(t)$ as a function of current time $t$ during the local night of a particular day and estimate the average amplitude $\langle A(t)\rangle$ as the function of the same time, but averaged during the period from one day to 30 days prior to the current date. Thus, we can find deviation $d A(t)=A(t)-<A(t)>$. By using this residue, we estimate trend of the nighttime average amplitude being the mean value of $d A(t)$ against the local time. The second parameter is the dispersion, which characterizes the rate of amplitude fluctuations around the average. These two parameters are independent random variables, and we normalize them by their standard deviations $(\sigma)$ in the interval 30 to 1 day before the current day. Further details of this nighttime fluctuation method might be found in $[16,17,20]$.

The definition of the ambient night is considerably complicated for the east-west longrange propagation from NLK to Japanese stations (such as CHF), the distance $D=7 \sim 8 \mathrm{Mm}$. By considering the sunrise and sunset at the transmitter and the observatory (the terminator times [26]) and by checking the real diurnal variations at the NLK-CHF path, we have chosen the universal time (UT) interval from $10 \mathrm{hr}$ to $12 \mathrm{hr}$ as the nighttime at particular path. That is, only during this period the propagation path is completely in the dark.

Fig. 2 illustrates relative location of two Russian observatories, PTK and YSH and the Japanese VLF/LF transmitters (JJY in Fukushima and JJI in Miyazaki). These latter might be seen in Fig. 1 as well. The wave sensitive areas for all propagation paths are also shown (i.e., JJY-YSH, JJY-PTK, JJI-YSH, and JJI-PTK) together with the locations of the main shock and aftershocks.

Next, we have to discuss the nighttime interval for the Russian data because we use the same nighttime fluctuation method. The February night lasts from UT $10 \mathrm{hr} 30 \mathrm{~min}$ to $18 \mathrm{hr} 40 \mathrm{~min}$, an the interval is $\mathrm{UT}=11: 00-16: 30$ during May.
Correspondingly, the nighttime for March and April is within this interval, as UT $=10: 30-11: 00$ for sunset and it is 16:30-18:40 for sunrise. The data analysis from Russian records is exactly the same as the above mentioned analysis of Japanese data.

The analysis period covered the interval from February 1 to May 22, 2011, including our target EQ on March 11.

3.1. Significant propagation anomalies associated with the propagation paths from American transmitter NLK. Fig. 1 suggests that the propagation paths from the American transmitter NLK (at Seattle, USA) to Japanese receiving stations (CHF, KSG, KCH) are favorably located with respect to the epicenter of this oceanic EQ. Especially, the NLK-CHF path is just above the EQ epicenter, and the corresponding wave sensitive area of this path is plotted by a thin elliptic line in Fig. 1. Two other propagation paths from NLK to KSG and from NLK to $\mathrm{KCH}$ (only the corresponding great-circle paths are shown) are also favorable for noticing corresponding ionospheric perturbations, although the sensitive areas were not shown for simplicity.

In accordance to theoretical expectations, Fig. 3 illustrates the experimentally observed evolution of propagation characteristics for the above paths. Fig. 3, a refers to the NLK-CHF path, Fig. 3, b, - to NLK-KCH path, and Fig. 3, c, - to the NLK-KSG path. We depict in Fig. 3 (from top to bottom) the trend and dispersion, normalized by their standard deviations $(\sigma)$.

Let us look at the top panel (trend) of Fig. 3, a presenting the most important propagation path NLK-CHF during the period from January 1. We see that trend does not fall down to $-2 \sigma$ level during the whole period, except the January 29 date and an exclusively significant propagation anomaly during two days of March 5 and 6. The anomaly of March 5 has a remarkable trend decrease exceeding $-3 \sigma$ and approaching $-4 \sigma$. Almost simultaneously, the second parameter (dispersion) increases approaching $+2 \sigma$. The anomaly is also recognized in Fig. 3, b for the propagation path from NLK to KCH. The anomaly for this path is rather evident in such a way that the most important parameter, trend exhibited a significant decrease reaching $-2 \sigma$ level. On the other hand, the anomaly for the NLK-KSG path (Fig. 3, c) is less pronounced during the same days of March 5 and 6. However, the overall VLF response to the EQ is very evident.

We must comment on other propagation anomalies seen in Fig. 3. In paper [16], we have tentatively chosen an EQ magnitude threshold of $M=6$ (this means rather strong Eqs only), and we have obtained a significant correlation exceeding the $2 \sigma$ criterion. However, even if we reduce the magnitude threshold to $M=5.5$, the correlation 
between VLF/LF anomalies and the EQs will be still significant: just around $2 \sigma$ level $[18,19]$. Therefore we must try to associate other depletions in trend of Fig. 3 to EQs in the relevant region. First of all, we comment on the anomaly on January 29 in Fig. 3, a.
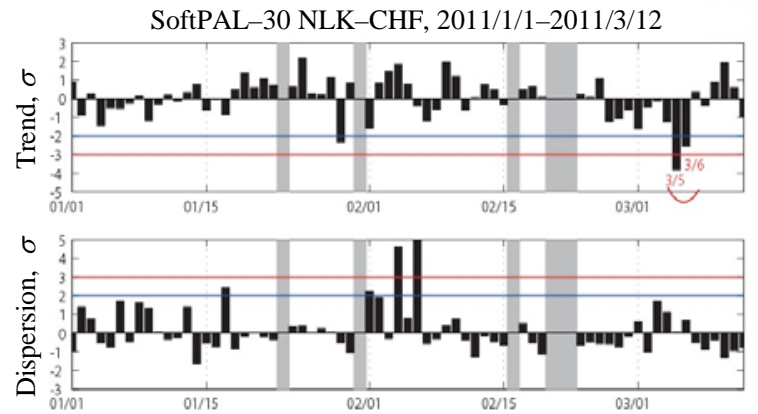

a)
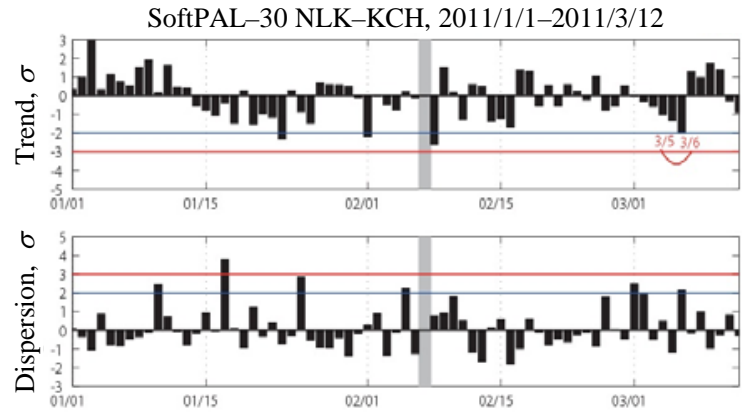

b)
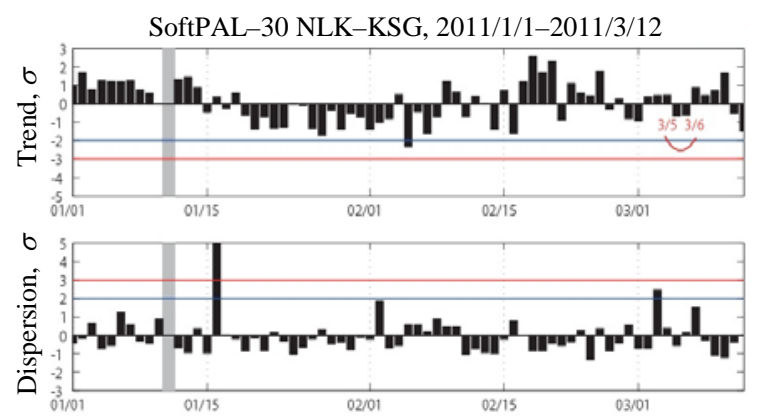

c)

Fig. 3. Evolutions of the propagation anomalies observed at three propagation paths: (a) NLK-CHF, (b) NLK-KCH and (c) NLK-KSG. The top panel of each frame refers to the normalized average nighttime amplitude (called trend), and the bottom panel shows the normalized dispersion. A clear anomaly is seen on March 5 and 6

This anomaly was probably associated with two EQs that occurred in the off-sea of Iwate (February 3) and Fukushima (on February 10, $M=5.3$ ). Further comments are required on other depletions in trend of Fig. 3, b. The depletion on January 23 is likely to be related with an EQ in the off-shore of Chiba on January $25(M=5.1)$. Then, the depletions in trend on February 1 and 8 (exceeding $-2 \sigma$ level) are likely to be related to another EQ in Chiba-oki on February $5(M=5.2)$ and to an EQ in the Miyagi-oki on February $15(M=5.5)$, respectively. Finally, the depletion on February 5 in Fig. 3, c is likely to be a precursor to an EQ in Fukushima-oki $(M=5.3)$.

3.2. Clear propagation anomaly for the propagation path from JJI to PTK. Among the three Russian propagation paths, we have found a possible effect only at the propagation path from JJI (Miyazaki, Kyushu) to Kamchatka (PTK). The top panel of Fig. 4 illustrates temporal evolution of the nighttime average amplitude (trend), and the second panel refers to the conventional dispersion. The bottom plot indicates the EQs occurrence of magnitude exceeding 5.5. The horizontal dotted lines indicate the $2 \sigma$ and $-2 \sigma$ levels.

Fig. 4 shows that a significant and extended decrease in the nighttime amplitude takes place during a rather long period from February 28 to March 6 on the path from JJI to PTK, with a maximum depletion on March 3 and 4. The corresponding increases in the dispersion are simultaneously observed, with the maximum on March 3 and 4. The dates with VLF/LF propagation anomaly on the Russian path are a slightly shifted against that of the NLK-CHF path in Fig. 3. Still, anomaly on this propagation path is considered to be the same, owing to some inhomogeneity in time and in space of the ionospheric perturbation (e.g., [27]).

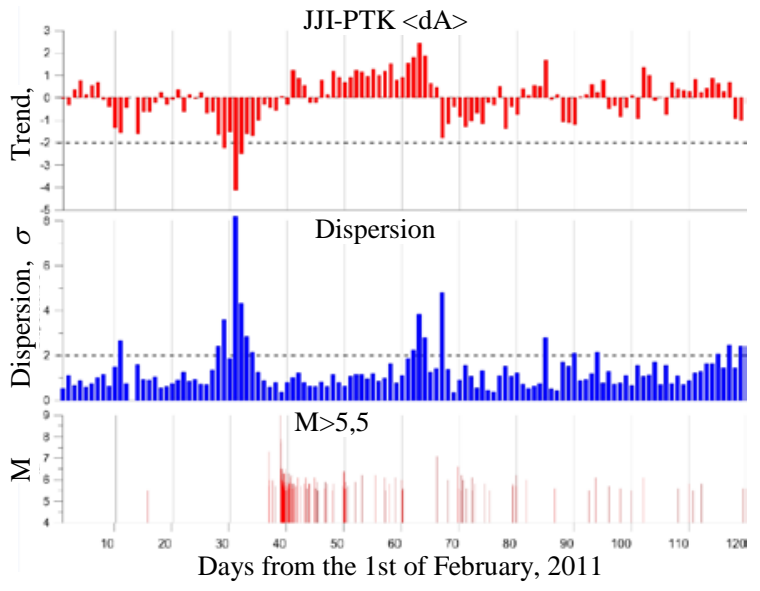

Fig. 4. Evolution of the propagation characteristics for the propagation path of JJI-PTK. The top panel shows the normalized average nighttime amplitude (trend). Horizontal dashed line indicates the level $-2 \sigma$. The middle panel depicts the normalized dispersion with the horizontal dashed line of $+2 \sigma$. The bottom panel demonstrates evolution of seismic activity

Finally, we comment on the last Russian path, JJY-PTK. The wave sensitive area for this propagation path is seen in Fig. 2. It is completely within the wave sensitive area of the abovementioned JJI-PTK path related to significant anomalies. Though not shown as a figure, it was found that trend showed a significant decrease on March 4, which did not exceed the $-2 \sigma$ level being approximately $-1.5 \sigma$. Anyway, an anomaly was 
observed at this path as well on March 4, but its nature indicates on highly non-uniform ionospheric perturbations.

Summary and discussion. By making full use of the Japanese-Russian sub-ionospheric VLF/LF network, the following observational facts have emerged in possible relation to the 2011 3.11 Japan EQ.

No definite anomaly was detected at the paths JJY-MSR, JJY-YSH and JJI-YSH.

On the other hand, the clear and significant anomalies were observed at the two propagation paths of NLK-Japanese stations (CHF, KSG and $\mathrm{KCH}$ ) and JJI-PTK. The anomaly of the path NLK-CHF took place on March 5 and 6 as a significant decrease in trend (nighttime average amplitude) exceeding the $-3 \sigma$ level, accompanied by simultaneous increase in dispersion. The anomaly on the path JJI-PTK shows a broad depletion from February 28 to March 6, with maximum depletions on March 3 and 4, which is also characterized by a significant decrease in trend and an increase in dispersion. So, the remarkable ionospheric perturbation is likely to be persistent, at least, for 4 days (March 3-6).

Though not shown due to the limit of space, we have tried to demonstrate that anomalous changes in VLF/LF propagation summarized above, would be likely relevant to the March 3 EQ. The following points have been addressed one by one: (1) how distinct is the VLF/LF propagation anomaly and the significance using the conventional standard deviation, (2) what is the temporal evolution of terminator times (significant changes in terminatortimes), (3) were there any solar-terrestrial effects in the VLF/LF propagation, especially, the geomagnetic storms, (4) effects of other EQs and foreshock activities on the VLF anomaly, (5) correlation of the present anomaly with other phenomena, and (6) other examples of $V L F / L F$ propagation anomaly for oceanic EQs.

\section{References}

1. Hayakawa M. Seismo-Electromagnetics: Lithosphere Atmosphere - Ionosphere Coupling / M. Hayakawa, O. A. Molchanov. - Tokyo: TERRAPUB, 2002. - 477p.

2. Pulinets S. A. Ionospheric Precursors of Earthquakes / S. A. Pulinets, K. Boyarchuk. - Berlin: Springer, 2004. - 215 p.

3. Molchanov O. A. Seismo Electromagnetics and Related Phenomena: History and latest results / O. A. Molchanov, M. Hayakawa. - Tokyo: TERRAPUB, 2008. - 189 p.

4. Hayakawa $M$. Electromagnetic Phenomena Associated with Earthquakes / M. Hayakawa (ed.). - Trivandrum (India): Transworld Research Network, 2009. - 279 p.

5. Uyeda $S$. Short-term earthquake prediction: Current state of seismo-electromagnetics / S. Uyeda, T. Nagao, M. Kamogawa // Tectonophys. - 2009. - 470, iss. 3-4. - P. 205-213.

6. Hayakawa $M$. Current status of seismo-electromagnetics for short-term earthquake prediction / M. Hayakawa, Y. Hobara // Geomatics, Natural Hazards and Risk. - 2010. - 1, N 2. P. 115-155.

7. Varotsos P. The Physics of Seismic Electric Signals / P. Varotsos. - Tokyo: TERRAPUB, 2005. - 329 p.
8. Hayakawa M. Monitoring of ULF (ultra-low-frequency) geomagnetic variations associated with earthquakes / M. Hayakawa, K. Hattori, K. Ohta // Sensors. - 2007. - $\underline{7}$, N 7. - P. 1108-1122.

9. Fraser-Smith A. C. The ultra-low-frequency magnetic fields associated with and preceding earthquakes // Electromagnetic Phenomena Associated with Earthquakes / A. C. Fraser-Smith; ed. by M. Hayakawa. - Trivandrum (India): Transworld Research Network, 2009. - P. 1-20.

10. Kopytenko Yu. A. Study of local anomalies of ULF magnetic disturbances before strong earthquakes and magnetic fields induced by tsunami // Electromagnetic Phenomena Associated with Earthquakes / Yu. A. Kopytenko, V. S. Ismaguilov, L. V. Nikitina; ed. by M. Hayakawa. - Trivandrum (India): Transworld Research Network, 2009. - P. 21-40.

11. Hayakawa M. The Frontier of Earthquake Prediction Studies / M. Hayakawa. - Tokyo: Nihon-senmontosho-Shuppan, 2012. $800 \mathrm{p}$.

12. Hayakawa M. Seismogenic pertubation in the atmosphere // Electromagnetic Phenomena Associated with Earthquakes / M. Hayakawa; ed. by M. Hayakawa. - Trivandrum (India): Transworld Research Network, 2009. - P. 119-136.

13. Hayakawa M. Lower ionospheric pertubations associated with earthquakes, as detected by subionospheric VLF/LF radio waves // Electromagnetic Phenomena Associated with Earthquakes / M. Hayakawa; ed. by M. Hayakawa. Trivandrum (India): Transworld Research Network, 2009. P. 137-185.

14. Liu J. Y. Earthquake precursors observed in the ionospheric Fregion // Electromagnetic Phenomena Associated with Earthquakes / J. Y. Liu; ed. by M. Hayakawa. - Trivandrum (India): Transworld Research Network, 2009. - P. 187-204.

15. Parrot $M$. Anomalous seismic phenomena: View from space // Electromagnetic Phenomena Associated with Earthquakes / M. Parrot; ed. by M. Hayakawa. - Trivandrum (India): Transworld Research Network, 2009. - P. 187-204.

16. Hayakawa $M$. A statistical study on the correlation between lower ionospheric perturbations as seen by subionospheric VLF/LF propagation and earthquakes / M. Hayakawa, Y. Kasahara, T. Nakamura et al. // J. Geophys. Res. - 2010. 115. - A09305 (9 p).

17. Hayakawa $M$. On the correlation between ionospheric perturbations as detected by subionospheric VLF/LF signals and earthquakes as characterized by seismic intensity / M. Hayakawa, Y. Kasahara, T. Nakamura et al. // J. Atmos. Solar-terr. Phys. - 2010. - 72, iss. 13. - P. 982-987.

18. Rozhnoi A. Middle latitude LF $(40 \mathrm{kHz})$ phase variations associated with earthquakes for quiet and disturbed geomagnetic conditions / A. Rozhnoi, M. S. Solovieva, O. A. Molchanov, M. Hayakawa // Phys. Chem. Earth. - 2004. 29, N 4. - P. 589-598.

19. Maekawa S. A statistical study on the effect of earthquakes on the ionosphere, based on the subionospheric LF propagation data in Japan / S. Maekawa, T. Horie, T. Yamauchi et al. // Ann. Geophysicae. - 2006. - 24. - P. 2219-2225.

20. Kasahara $Y$. On the statistical correlation between the ionospheric perturbations as detected by subionospheric VLF/LF propagation anomalies and earthquakes / Y. Kasahara, F. Muto, T. Horie et al. // Natural Hazards Earth System Sci. - 2008. - 8 , iss. 4. - P. 653-656.

21. Hayakawa M. Summary report of NASDA's earthquake remote sensing frontier project / M. Hayakawa, O. A. Molchanov, NASDA/UEC team // Phys. Chem. Earth. 2004. - 29, N 4-9. - P. 617-625.

22. Hayakawa M. Subionospheric VLF/LF probing of ionospheric perturbations associated with earthquakes: A possibility of earthquake prediction / M. Hayakawa, T. Horie, F. Muto et al. // SICE J. Control, Measurement, and System Integration (SICE JCMSI), 2010. - 3, N 1. - P. 10-14.

23. Rozhnoi A. Observation evidences of atmospheric gravity waves induced by seismic activity from analysis of subionospheric LF signal spectra / A. Rozhnoi, M. Solovieva, O. Molchanov et al. // Natural Hazards Earth System Sci. 2007. - 7, N 5. - P. 625-628. 
24. Rozhnoi A. Search for electromagnetic earthquake precursors by means of sounding of upper atmosphere-lower ionosphere boundary by VLF/LF signals, // The Frontier of Earthquake Prediction Studies / A. Rozhnoi, M. Solovieva, M. Hayakawa; ed. by M. Hayakawa. - Tokyo: Nihon-senmontosho-Shuppan, 2012. - P. 652-677.

25. Rozhnoi A. Ionospheric turbulence from ground-based and satellite VLF/LF transmitter signal observations for the Simushir earthquake (November 15, 2006) / A. Rozhnoi, M. Solovieva, M. Parrot et al. // Ann. Geophysics (Italy). 2012. - 55, N 1. - P. 187-192.

26. Hayakawa $M$. The precursory signature effect of the Kobe earthquake on VLF subionospheric signals / M. Hayakawa, O. A. Molchanov, T. Ondoh, E. Kawai // J. Comm. Res. Lab. 1996. - 43. - P. 169-180.

27. Yamauchi T. Subionospheric VLF/LF monitoring of ionospheric perturbations for the 2004 Mid-Niigata earthquake and their structure and dynamics / T. Yamauchi, S. Maekawa, T. Horie et al. // J. Atmos. Solar-terr. Phys. 2007. $-\underline{69}$, iss. 7. - P. 793-802.

\section{Manuscript received July 13, 2012.}

М. Хаякава, Я. Хобара, А. Рожной, М. Соловьева, К. Ота, Дж. Изуцу, Т. Накамура, Я. Ясуда, Х. Ямагучи, Я. Касахара

ИОНОСФЕРНЫЙ ПРЕДВЕСТНИК ЗЕМЛЕТРЯСЕНИЯ 11 МАРТА 2011 Г ПОНАБЛЮДЕНИЯМ ТРАНСТИХООКЕАНСКОГО РАСПРОСТРАНЕНИЯ СДВ/ДВ-РАДИОВОЛН НА СЕТИ СТАНЦИЙ

\footnotetext{
Используя наблюдения распространения СДВ/ДВ-радиоволн над Тихим океаном на японской и российской сети станций, удалось обнаружить значительное возмущение ионосферы, предшествовавшее последнему мощному землетрясению в Японии 11.03.2011 г. Эпицентр землетрясения находился в море, в области Тохоку, а само событие относится к исключительно мощным землетрясениям, связан-
}

ным с перемещением тектонических плит. Явно выраженная аномалия (уменьшение ночной амплитуды сигнала при увеличении ее дисперсии) была обнаружена 5 и 6 марта на трассе распространения от передатчика NLK (Сиэтл, США) к наблюдателю в Чофу, Япония (аналогичные явления - на трассах распространения в Кочи и Кацугаи). Аналогичная длительная аномалия в СДВ-распространении регистрировалась с 1 по 6 марта с минимальной ночной амплитудой 3 и 4 марта на трассе от передатчика JJI (Миязаки, Кюсю) до Камчатки, Россия.

Ключевые слова: ионосферный предвестник, волноводное СДВ/ДВ-распространение, японское землетрясение 11 марта 2011 г.

М. Хаякава, Я. Хобара, О. Рожной, М. Соловйова, К. Ота, Дж. Изуцу, Т. Накамура, Я. Ясуда,

Х. Ямагучі, Я. Касахара

\section{ІОНОСФЕРНИЙ ПРОВІСНИК ЗЕМЛЕТРУСУ 11 БЕРЕЗНЯ 2011 p. ЗА СПОСТЕРЕЖЕННЯМ ТРАНСТИХООКЕАНСЬКОГО ПОШИРЕННЯ СДВ/ДВ-РАДІОХВИЛЬ НА МЕРЕЖІ СТАНЦІЙ}

Використовуючи спостереження поширення СДВ/ДВ-радіохвиль над Тихим океаном на японській i російській мережі станцій, вдалося виявити значне збурення іоносфери, що сталося перед останнім потужним землетрусом у Японії 11.03.2011 р. Епіцентр землетрусу знаходився в морі, в області Тохоку, а сама подія відноситься до виключно потужних землетрусів, пов'язаних 3 переміщенням тектонічних плит. Явно виражена аномалія (зменшення нічної амплітуди сигналу при збільшенні іiі дисперсії) було виявлено 5 та 6 березня на трасі від передавача $N L K$ (Сіетл, США) до спостерігача в Чофу, Японія (аналогічні явища - на трасах поширення до Кочі й Кацугаї). Аналогічну тривалу аномалію в СДВ-поширенні реєстрували 31 по 6 березня 3 мінімальною нічною амплітудою 3 і 4 березня на трасі від передавача $J J I$ (Міязакі, Кюсю) до Камчатки, Росія.

Ключові слова: іоносферний провісник, хвилевідне СДВ/ДВ-поширення, японський землетрус 11 березня 2011 p. 